\title{
交通事故多発交差点に関する事故要因分析システムの構築* Construction of Analysis System for Traffic Accidents Estimation in Intersection ${ }^{*}$
}

\author{
村瀬 満記**秋山 孝正 ${ }^{* * *}$ 奥嶋 政嗣**** \\ Mitsunori MURASE $E^{* *}$, Takamasa AKIYAMA ${ }^{* * *}$ Masashi OKUSHIMA***
}

\section{1.はじめに}

都市道路網における有効な交通安全対策立案のた めには、交通事故多発交差点における的確な交通事 故要因の把握が必要不可欠である。都市内街路にお ける交差点は、規模、形状、交通状況など多様な要 素が複雑に関連しており、交通事故要因の把握のた めには、これらの項目相互の関連性および交通事故 発生との因果関係を、交通事故要因に関わる知見と して蓄積し、分析・検証する必要がある。

このため本研究では、交通事故多発地点での事故 発生要因に関する多様なデータ項目を、データベー スとして整理する。これを利用し、交通事故に関す る統合的な分析システムを構筑する。具体的には、 まず交通事故発生要因を分析する。その上で、事故 発生に関する知識を獲得する。これをもとに交通事 故推計における推論のルールを作成し、都市内街路 における交差点での事故件数推計を行う。この結果 をもとに、効果的な安全対策の導出を行う。

\section{2. 交通事故多発地点データベースシステムの提案}

交通事故は多くの要因が複雑に関連して発生する。 これを把握するため、交通事故に関連する多様な項 目をデータベースとして整理する。これを用いて、 交通事故発生要因に関連する分析を行う。ここでは、 この一連の流れを行うことのできる交差点交通事故 に関する統合的な分析システムを作成する。

\section{(1) データベースシステムの概要}

データベースシステムの構成と、このシステムが

内包する各種機能の関連性について述べる。

(a) データベースシステムの構成

システムの構成を図ー1 に示す。交通事故の発生

キーワーズ : 交通事故, 交差点, データベース, 知識獲得

** 学生会員, 岐阜大学大学院 工学研究科

*** 正会員, 工博, 岐阜大学 工学部社会基盤工学科

**** 正会員, 工修, 岐阜大学 工学部社会基盤工学科

（ テ501-1193 岐阜市柳戸 1-1，TEL:058-293-2446,

E-mail:okushima@cc.gifu-u.ac.jp
に関連する要因として、交差点事故、交差点構造、 交通安全対策を、それぞれデータセットとして整理 する。これを、交通流動、知識、推論ルールをそれ ぞれ統括するデータベースと連動させることで、各 種機能の実行を可能にしている。具体的には、交通 事故件数の集計、知識の獲得、交通事故件数推計な どの機能である。また、このシステムは GIS との連 動を図ることで、詳細な位置情報の提供が可能とな っている。さらに、このシステムは任意のユーザー による利用が可能である。以下、システムが内包す る各種の機能について説明する。

(1)「事故分析」機能 : 各交差点において発生した交 通事故を、年次別、月別、時間帯別、事故類型別、 天候別などの項目別に集計することができる。ま た、交通事故発生状況図を表示することにより、 交差点内において発生した個々の事故の発生箇所 を確認することができる。

(2)「知識獲得」機能 : 分析システム内の「交差点事 故ベース」、「交差点構造ベース」に格納される データをもとに、コンピュータが交通事故の発生 にかかわるルールを生成していく。

(3)「データ更新」機能 : ユーザーが「事故分析」機 能により、事故分析図などを分析し、事実を整理 する。これにより得られた知識を、随時「知識べ 一ス」に蓄積していく役割を担う。また、警察な どの専門家から得た知識を知識ベースに格納する。

(4)「事故件数推定」機能：「知識ベース」に格納さ れた知識をもとに、交通事故推計を行う。ユーザ

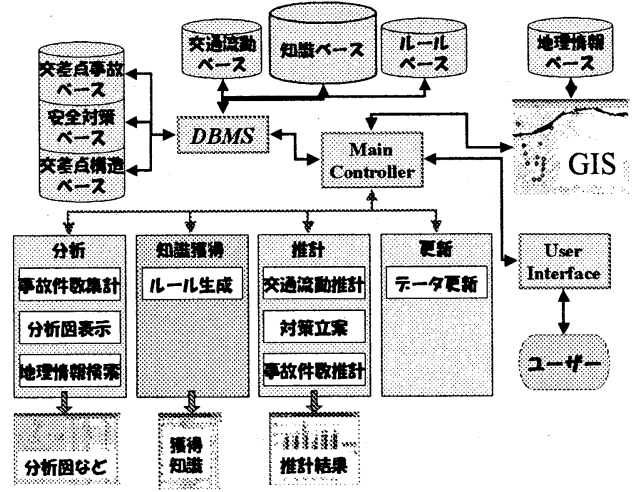

図-1 データベースシステムの構成 
一がこの推計結果を分析し、各交差点において有 効な対策案を立案していく。

(b) 事故要因分析機能の関連性

各機能の関連性を図ー2に示す。まずユーザーが、

「交差点事故ベース」に格納されるデータを、「事 故件数集計」などの機能により、目的に応じて分析 する。これにより、交通事故発生に関する事実を把 握する。その上で、事故発生要因に関する知識とし て整理する。ここで、知識を警察などの専門家から も得るようにする。この手順で得られた知識を「知 識ベース」に格納する。また、システム内でコンピ ユータが行う「知識獲得」機能によっても知識を獲 得していく。さらに、この知識ベースに蓄積された 知識から、推論ルールを生成し、事故件数推計を行 う。これにより得られた結果をユーザーが分析し、 効果的な対策案を立案する。

\section{（2）交通事故関連データの整理}

本研究では岐阜市内の交通事故多発交差点を対象 とし、交通事故発生状況、交差点構造、交通安全対 策、交通量などの 8 区分のデータセットからなるデ ータベースを構筑する。データ項目の一覧を表一 1 に示す。各データセットはデータキー項目により関 連付けられ、連結して分析可能となっている。

「事故デー夕」については、個々の事故データを 整理した ${ }^{1)}$ 。発生年月日、発生時刻、事故形態、天 候について記録し、発生位置については、詳細デジ タル地図と連動させた。「事故件数データ」につい ては、年次別、事故形態別に集計し、経年的な変化 を分析可能としている。「交差点構造データ」につ いては、交差点全体で固有のデータと、流出入部ご とに設定すべき項目を分類し、それぞれのデータに ついて数値データ化した。有無のみが判別できる項 目については無：0/有：1 で入力した。「安全対策 データ」については、交差点別、年次別に実施され た安全対策の数值データ化と、種類別の一覧と対策 に付記されたコメントも整理した。これらは事故対 策図より設定した。「交通量データ」については、 第 3 回中京都市圈 $\mathrm{P}$ T調査および平成 8 年度中京 $\mathrm{P}$ T中間年次調査を参考とした。平成 3 年および平成 8 年の OD表を作成し、各年次の O D 表を線形補完 により作成した。ここで岐阜市内の道路ネットワー クデータを使用して交通量配分計算を行い、各交差 点における方向別流入交通量を算出した。

\section{（3）データベースの利用方法}

分析システムは、交通事故要因分析のための各機

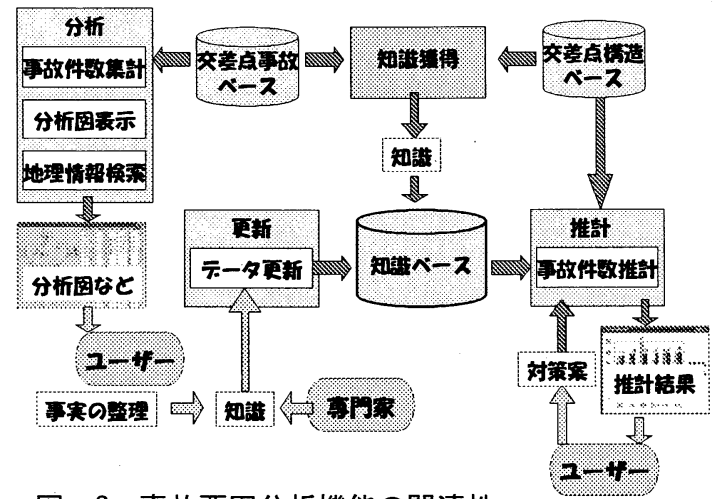

図-2 事故要因分析機能の関連性 表一1 データ項目一覧

\begin{tabular}{|c|c|c|c|}
\hline 区分 & 項目 & Length & 内容など \\
\hline \multirow{8}{*}{ 交通事故 } & *事故ID番号 & 7 & 事故ID \\
\hline & *交差点 & 4 & ID番号 \\
\hline & *年次 & 4 & 1996-2003 \\
\hline & 発生箇所 & 25 & GIS座標 \\
\hline & 発生月日 & 4 & 月日 (4桁) \\
\hline & 発生時刻 & 4 & 時:分 00:00 \\
\hline & 事故類型 & 1 & 5区分 \\
\hline & 天候 & 1 & 4区分 \\
\hline \multirow{4}{*}{$\begin{array}{c}\text { 交通事故 } \\
\text { 件数 }\end{array}$} & *交差点 & 4 & 1D番号 \\
\hline & * 年次 & 4 & $1996-2003$ \\
\hline & *事故類型 & 1 & 5区分 \\
\hline & 事故件数 & 3 & (数値)集計値 \\
\hline \multirow{11}{*}{$\begin{array}{c}\text { 交美点 } \\
\text { 構造 } \\
\text { (固有) }\end{array}$} & *交差点 & 4 & ]D番号 \\
\hline & 名称 & 20 & (文字列) \\
\hline & 形状 & 1 & 十字路，3叉路 \\
\hline & 流入方向数 & 2 & (数値) \\
\hline & 流出方向数 & 2 & (数值) \\
\hline & 面積 & 5 & (数值) \\
\hline & 総車線数 & 2 & (数値) \\
\hline & 信号灯栰数 & 2 & (数值) \\
\hline & 最小交差角度 & 3 & (数值) \\
\hline & 路面電車有無 & 1 & 1:有 $/ 0$ :無 \\
\hline & 図面ID & 5 & 図面ファイル番号 \\
\hline \multirow{13}{*}{$\begin{array}{c}\text { 交差点 } \\
\text { 構造 } \\
\text { (方向別) }\end{array}$} & *交差点 & 4 & ID番号(名称) \\
\hline & *方向 & 2 & 流出入No. \\
\hline & 車線数 & 2 & (数值) \\
\hline & 右折車線数 & 2 & (数值) \\
\hline & 左折車線数 & 2 & （数值） \\
\hline & 下り勾配車線数 & 2 & (数值) 分析図より \\
\hline & 減少車線数 & 2 & 流出部の車線減少 \\
\hline & 街路数 & 2 & (数值)分析図より \\
\hline & 規制速度 & 3 & (数値) \\
\hline & 進入速度 & 3 & (数值):未計測 \\
\hline & 形状の特異性 & 1 & 1:直 $/ 0$ :無 \\
\hline & 路面電車有無 & 1 & 1:有 $/ 0$ :無 \\
\hline & 交差角度 & 3 & (数値) \\
\hline \multirow{4}{*}{$\begin{array}{c}\text { 実施 } \\
\text { 安全対策 }\end{array}$} & *交差点 & 4 & ID番号 \\
\hline & *年次 & 4 & 1996-2003 \\
\hline & *種類 & 3 & ID(別途対策一臨) \\
\hline & 数量 & 5 & (数値) or 1 :有 $/ 0$ :無 \\
\hline \multirow{3}{*}{$\begin{array}{c}\text { 安全対策 } \\
\text { 一覧 }\end{array}$} & *種類 & 3 & 安全対策ID \\
\hline & 数量単位 & 5 & (文字列) \\
\hline & 内容 & 100 & (文字列)説明文 \\
\hline \multirow{5}{*}{ 交通量 } & *交差点 & 4 & ID番号 \\
\hline & *年次 & 4 & $1996-2003$ \\
\hline & *方向 & 2 & 流出入No. \\
\hline & 車種 & 1 & 1:普通 $/ 2:$ 大型 \\
\hline & 台数 & 6 & (数值) \\
\hline \multirow[t]{2}{*}{ 対策図 } & 图面ID & 5 & 図面ファイル番号 \\
\hline & 図面画像File & - & Jpeg形式 \\
\hline
\end{tabular}


能を内包する。このシステムの初期画面を図ー3 に 示す。ここで、例として、「事故分析」機能につい て説明する。この機能は、構築したデータベースに 格納されるデータを、目的に応じて取り出し、利用 することを可能としている。ここでは、市民会館前 交差点の場合を例に挙げる。この交差点は、JR 岐阜 駅の北約 $1.7 \mathrm{Km}$ の場所に位置し、岐阜市内の幹線道 路が交差する交差点である。交通事故は、毎年 35 件 程度発生している。H 8 と $\mathrm{H} 9$ の類型別事故件数の比 較を図ー4に示す。これによると、H8 からH9 にかけ て追突、その他（接触など）の事故が増加している ことが伺える。この原因として、H9 に実施された、 岐阜市を流れる長良川に架かる金華橋の改修工事が 挙げられる。これに伴い、交通流の変化が生じ、交 通事故が増加したと考えられる。

この交差点の構造的な特徴は、(1)北側市道がリバ ーシブルレーン構造になっており、時間帯によって 中央線が変化する。(2)車線が交差点南側から北側一 向けて減少しており、車線が食い違いになっている。 (3)道路交差角度が $90^{\circ}$ でない。がある。

また、H12 における市民会館前交差点の交通事故 の詳細表示を図-5 に示す。この画面は、「事故分 析」機能において、「事故詳細表示」を行った場合 の表示である。個別事故の発生時刻、発生場所、事 故類型などの情報を確認することができる。

\section{3. 交差点における交通事故要因分析}

交通事故多発地点データベースの構築により、い くつもの視点から交通事故要因を分析可能にした。 このデータベースを利用して、交差点交通事故要因 に関する知見を分析し、整理していく。

\section{（1）交通事故要因の分析手順}

交通事故発生要因に関する分析の手順を示す。以 下、本研究で規定した知識獲得の手順(1)〜 (7)を示す。 (1)基礎的統計資料による知識整理：「交通事故多発 場所マップ」、「ぎふ交通情勢」など基本的な統 計資料から、交通事故要因に関寸る全体的な傾向、 統計的な傾向を整理する。また、詳細地図により、 交差点形状などに特殊な要因について確認する。

(2)経年的事故件数推移と安全対策の関係整理：「事 故対策図」におけるコメントや対策実施位置によ り、交通安全対策の意図を把握する。また、交通 安全対策と、事故件数の経年的な変化とを対比し、 それぞれの効果の程度を整理する。

(3)空間的な事故発生要因の分析 : 年次別 - 交差点別

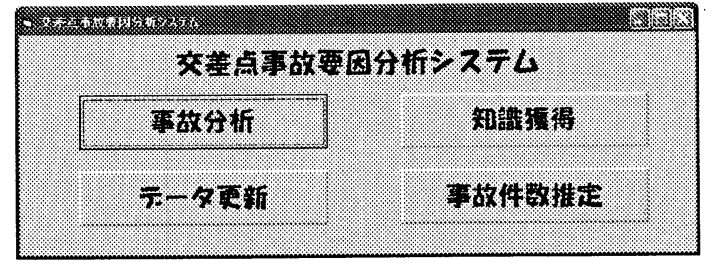

図-3 分析システム初期画面

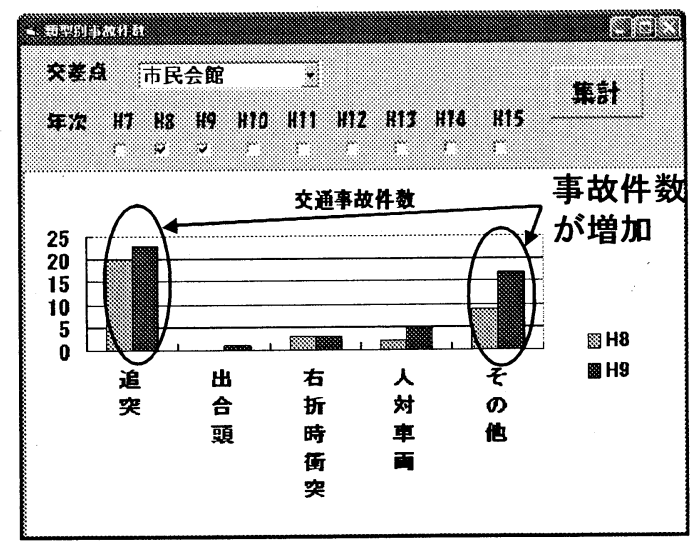

図-4 交通事故件数の類型別集計

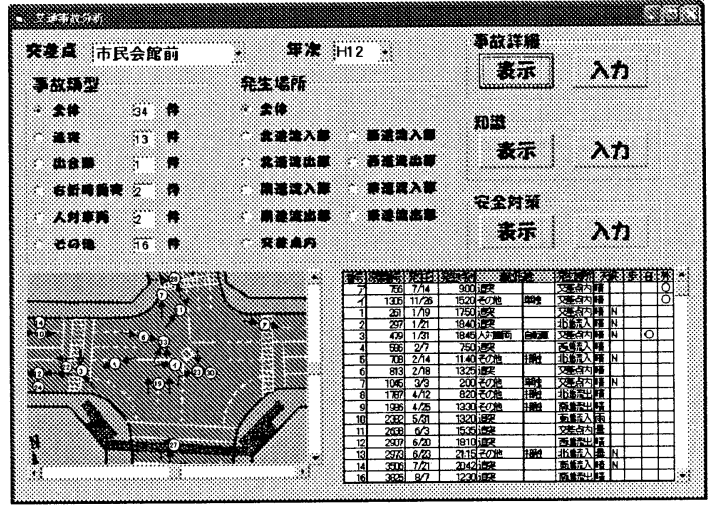

図-5 交通事故発生状況の詳細表示

に作成された「交通事故多発交差点別分析図」を 用いて、事故 1 件ずつについて、空間的な要因を 考察する。同一交差点での同様な知識は集約する。 (4)専門家へのインタビュー : 交通事故対策の専門家 へのインタビューを行う。ここで専門家とは、交 通管理者、道路管理者、学識経験者など地方自治 体が主催する交通事故防止に関する公式会議の参 加者を指す。このとき、これまでの知識整理では 表現できていない経年変化のある交差点や、矛盾 している知識について確認する。

(5)数值データによる要因分析 : 個々の事故について 記録されている発生時刻、発生年月、天候などの 数值データについて、事故類型や流出入部ごとの 
特徵について集計分析する。

(6)現地での観察 : 現地に赴き、車両の軌跡、進入速 度など、流動の様子を観察する(このとき同時にビ デオ撮影を行う)。また、各流入部から交差点まで の見通しについても観察する。

(7)ビデオ解析 : 撮影された交差点内および流出入部

の流動状況を数值情報に変換し、特徵を解析する。

ここでは、交通事故多発地点を対象とした交通事 故発生件数の多少に関する分析を行った。ここで、 交通事故発生件数の分析に加えて、利用者が感じる 危険感まで分析範囲を広げる場合には、Conflict Analisys の必要性が高いものと考えられる。

\section{（2）交通事故要因分析から得られた知見の蓄積}

ここでは、知識の蓄積に関して、前節で整理した 知識獲得手順(1)～(7) と獲得された知識の関係につい て説明する。獲得された交通事故要因に関する知識 は、対象とした交差点ごとに、知識獲得の手順(1) (7)と対応により順序付けされる。この順序にしたが って、「知識順序番号」が割り当てられる。また、 個々の知識を識別するための知識番号は、く(交差点 番号)-(知識順序番号) 〉と規定される。

つぎに、交通事故要因に関する知識の蓄積状況に ついて整理する。本研究では、岐阜市の交通事故多 発交差点 24 箇所を対象交差点として選定している。 これらの交差点 1 箇所につき、十数個程度の知識を 獲得した。多い箇所では 20 程度、少ない箇所で 10 程度の知識を整理した。この結果、全体で 300 程度 の知識を獲得した。これらの中には、同様の知識と して統合できるものが含まれるため、これを集約す ると、総知識数は 100 程度となっている。

具体例として、市民会館前交差点に関しての獲得 知識を図ー6に示す。また、図に示した手順番号は、 前節の知識獲得の手順(1)〜 (7)に対応している。知識 にはあいまい性を含む言語表現を用いている。これ らの言語表現の量的な関係には基本的に基準がある。 この基準は、知識獲得手順ごとにそれぞれ相違する。

手順(1) 手順(3)は、交通事故に関連する基礎統計 資料から知識獲得を行っているため、それぞれの出 典資料に記される量的な大小関係が基準となる。

また、手順(4)では専門家へのインタビューにより 知識獲得を行っているため、専門家の公の場での議 論によって導き出された共通認識が基準となる。

さらに、手順(5)では個々の交通事故記録に基づい た分析よる知識であり、分析結果として量的基準が 存在する。手順(6)、手順(7)においても同様に、現地 での観測が基礎データとなり、実際の現場において

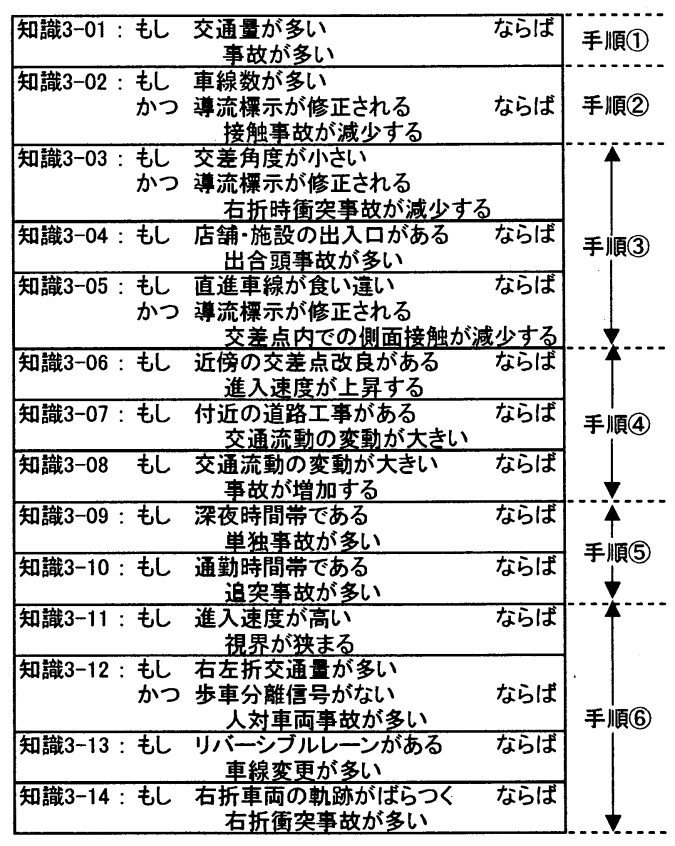

図一6 整理した知識の例 （市民会館前交差点の場合）

観測されたデータの分析結果が量的な基準となる。

ここで、手順(4)「専門家へのインタビュー」によ り獲得した知識に関しては、交通事故対策に関わる 専門家による公の場における議論に基づくものであ る。このため、担当者の主観による大きなバイアス は生じないと考えられる。また，手順(4)を以外の手 順により獲得した知識に関しては、それぞれについ て基礎となる客観的データが存在している。

整理した結果、手順(6)により獲得された知識が最 も多く、事故要因の分析のためには、現地での観察 が重要であることが確認できる。また、手順(3)で利 用した事故多発地点の分析図面の例を図ー7に示す。

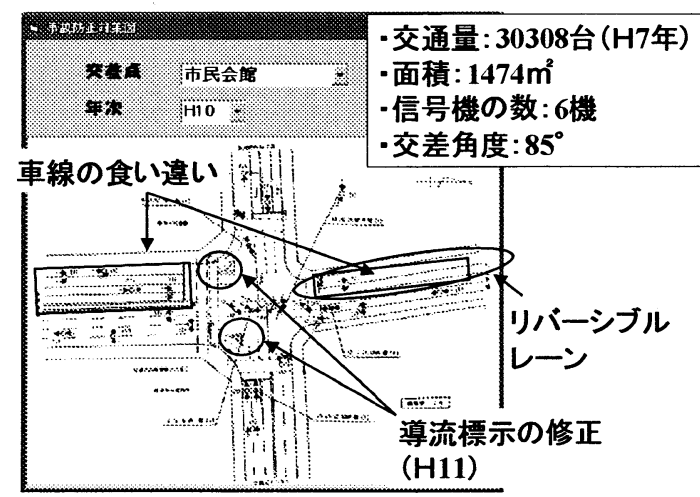

図-7 交通事故多発地点の分析図面 
ここで例として、交通事故件数についての量的基 準について具体的な数值で示寸。図ー8に、H14にお ける岐阜市中心市街地の交通事故多発地点を示す。 岐阜市交差点 1 箅所につき 1 年間に発生する交通事 故が、10 件程度 : 少ない、30 件程度 : 中くらい、50 件程度: 多い、80 件程度 : 非常に多いとなる。

また、前述のように各知識はそれぞれの手順ごと で知識獲得方法が異なる。ここで、手順(1)〜(3)では、 一般の統計データなどから知識を得ている。そのた め、必然的に一般的知識も多く含まれることとなる。

一方で、手順(4による知識は、実際の現場におい て交通安全対策を立案する専門家から獲得している。 このため、有用な知識が多く含まれる。

以下、整理した知識のうちのいくつかを例として 取り上げ、説明していく。

(1)「知識 3-01」: 交通事故の発生は、交通量の大 小に大きく関係する。このように交通量の多い交 差点では、交通混雑が発生しやすく、錯綜が生じ、 追突をはじめとする各種の事故が多く発生する。

(2)「知識 3-02」：車線数が多い場合、車両が車線 変更をすることが多く、車両相互の側面接触事故 が多くなる。このような交通の錯綜を防止する目 的として、H11 には「導流標示の修正」の交通安 全対策が実施された。これにより、各車線におけ る車両の進行方向が明確に示され、車両相互の接 触事故などが減少する。

(3)「知識 3-03」：道路の交差が直角でない変形交 差点の場合、道路交差が直角である交差点に比べ て、右折車両の右折時の走行軌跡が不安定になり やすい。この状況に対し、導流標示の修正を行う と、右折時衝突事故が減少する。

(4)「知識 3-05」：対象交差点の大きな特徴の一つと して、交差点の南北で道路が食い違い構造になっ ていることがある。この交差点構造は図ー7 の交 差点状況図より確認できる。このため、南側から 北側に向けて交差点を直進する車両の走行軌跡が 横方向に振れ、車両相互の側面接触などの交通事 故が多くなる。この状況に対し、導流標示の修正 を実施することで、側面接触事故が減少する。

(5)「知識 3-07」：対象交差点付近の道路・他交差 点において、道路工事が実施されると、道路の容 量が低下する。これより、道路区間の交通混雑が 発生し、工事箇所を迂回する交通が生成される。 これらのドライバーは不慣れな経路を走行するこ とになり、当該交差点における通常時の走行軌跡 の範囲を逸脱する車両もみられる。このため、通 常時とは異なった箇所での交通事故が多発する。

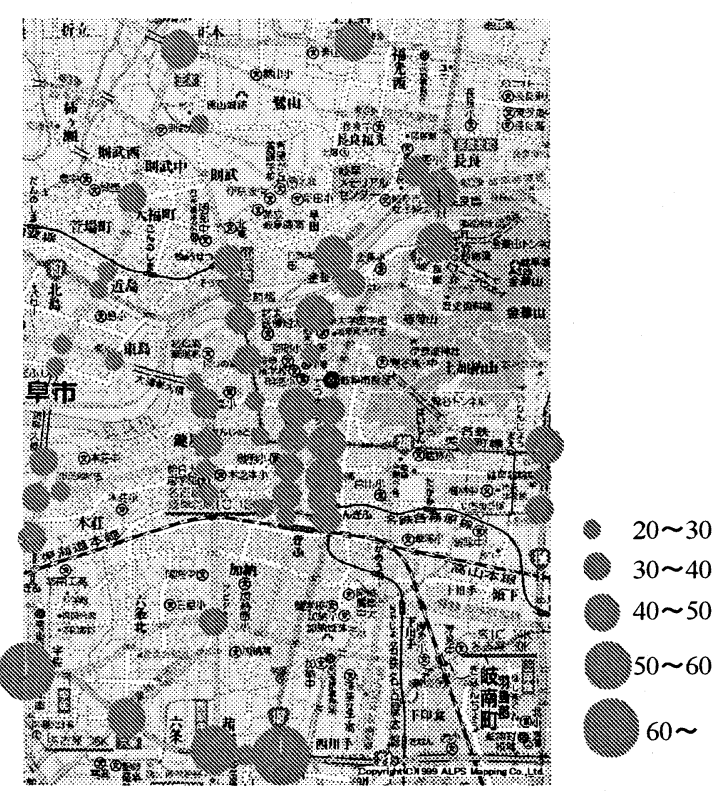

\section{図－8 岐阜市事故多発地点におけ る交通事故件数 (H14)}

(6)「知識 3-08」：近隣の道路区間の工事などによ り、部分的な流出入方向において交通流動変化が 発生する。このとき、特定の流入車線において流 入交通量が信号制御の設計範囲を超過する。

このため、信号現示変化時に高加速にて交差点 に進入する車両および車両行列末尾に到達する車 両が観測される。これらの車両による右折時衝突 および追突事故などが発生する。

(7)「知識 3-13」：前述のように、この交差点は道路 が南北で食い違っていることに加え、北側流出部 がリバーシブルレーン構造になっていることが図 ー7により確認できる。つまり、同一車線であつ ても時間帯によって、車線の進行方向が異なる。 これにより、車線変更時など、車両相互の錯綜が 生じ、側面接触などの事故が多発する。

\section{（3）蓄積された知見のルール化}

前節までにおいて、交通事故発生要因に関する知 識を蓄積した。ここでは、蓄積した知識をもとに交 通事故発生の要因を分析し、交通事故推計に用いる 推論ルールを作成する。つまり、交通事故の発生に 関連すると考えられる要因を抽出し、ルール化して いく。前節において蓄積した知識と、考えられるル ールとの対応を表ー2 に示す。例として、以下にい くつかの対応関係について説明する。

(1)「知識 3-02」と「ルール 1-15」・・車線数が多 く、車両が相互に錯綜する程度を「運転難易性」 
と考える。また、導流標示の修正が実施され、車 両が錯綜に対して安全に誘導できるようになるこ とを、「標示等誘導性」が大きくなることと捉え る。「知識 3-02」では、導流標示の修正により、 接触事故が減少することを述べている。「ルール 1-15」は、運転難易性が大きいにも関わらず、標 示等誘導性が小さい場合、車両誘導の容易さ「交 差点内制動容易性」が小さいことを述べる。

(2)「知識 3-12」と「ルール2-10」 ・ ・全交通量に 対する直進交通量の割合を「直進流動性」とし、

この值が小さい場合は右左折交通量が多いことを 意味する。右左折交通量が多く、かつ、歩車分離 信号などの歩行者・自転車に対する設備の設置度 合い「歩行者安全性」がない場合、右左折車と歩 行者・自転車の人対車両事故が多くなる。

上記のような対応付けを、各対象交差点について 行う。以上の分析から、交通事故に関わる要因の相 互関連性を図一9に示す。交通事故に関連する複数 の要因が、階層的な構造で繋がり、相互に関連して いると考える。「交通流」や「流動直進性」など、1 階層目に位置する要因は、多数の測定可能な変数か ら構成できるものである。これに対し、「停止容易 性」や、「交差点内制動容易性」は、中間の層に位 置し、複数の要因と関連する。例えば、「停止容易 性」は、「車線変形度」と「車両走行状態（スピー ド）」に関連する要因である。また、「交通流」、 「交差点規模」は、他の要因に比へ、交通事故の発 生に大きく影響するため、中間の層を経由せずに、 交通事故の発生に直接繋がる要因とする。この構造 においては、事故類型別に発生する要因を考える。

これをルール化したものを図ー10に示す。各ルー ルは、発生する事故類型ごとに生成される。例とし てルール 1-9 は、追突事故の要因を考慮しており、

「車線変形度が大きくない、かつ、車両走行状態 ( ス ピード）が小さくないならば、停止容易性は中くら いである」ことを示す。また、右折時衝突事故を考 慮したルール 2-9 は、「流動直進性が小さく、かつ、 交差点内制動容易性が大きくないならば、交通事故 は多い」ことを意味する。

\section{4. 交差点交通事故要因に関する知見の利用}

作成した交通事故要因に関するルールから、ファ ジィ推論を用いた交通事故件数推計モデルを構筑す る。ここでは、事故類型ごとの発生要因を考慮でき る事故件数推計モデルを構筑する。これにより、各 交差点の事故件数を推計する。
表 -2 知識とルールの対応関係

（市民会館前交差点の場合）

\begin{tabular}{|l|l|l|}
\hline \multicolumn{1}{|c|}{ 知識 } & \multicolumn{1}{|c|}{ ルール } \\
\hline 知識3-06 知識3-11 & Rule-1-1 & Rule-1-2 \\
知識3-03 知識3-05 & Rule-1-14 & \\
知識3-02 & Rule-1-15 \\
知識3-01 知識3-07 知識3-08 & $\begin{array}{l}\text { Rule-2-1 Rule-2-2 Rule-2-3 Rule-2-4 } \\
\text { 知識3-12 }\end{array}$ \\
\hline
\end{tabular}

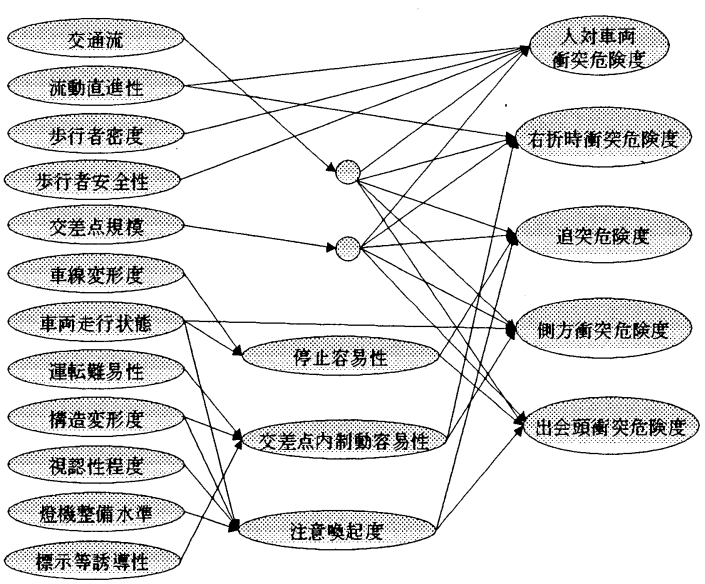

図-9 交通事故要因の関連性

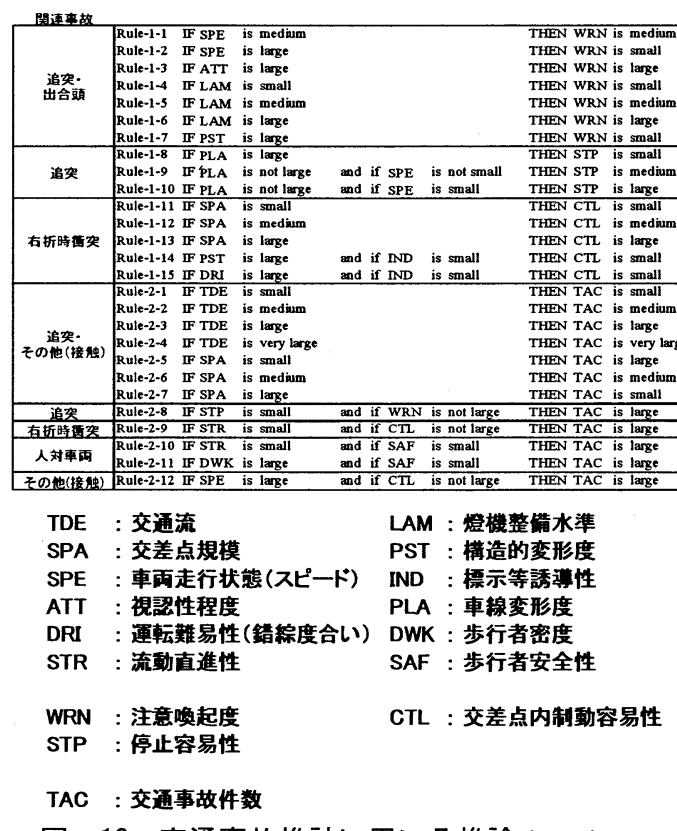

図-10 交通事故推計に用いる推論ルール

\section{（1）ファジィ推論モデルの段階的構造}

交通事故件数推計に関しては、既存研究において 階層型ニューラルネットワークを用いた事故類型区 分別推計モデルが提案されている ${ }^{2) ~ 5) 。 こ の モ テ ゙ ル ~}$ の推計精度は極めて高いが、説明変数（事故要因） と被説明変数 (事故件数)の因果関係が明確でない。 
本研究では因果関係を明確にすることが期待できる

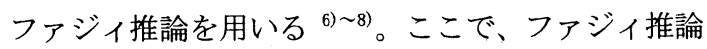
の基本的な構造について述べる ${ }^{9) \sim 11) 。 ~}$

ファジィ集合 A と B のファジィ関係 $\mathrm{R}$ とは両者の 関係を表現するファジィ集合である。具体的には

$$
R=\int_{X \times Y} \mu_{R}(x, y) /(x, y)
$$

のように表現される。このメンバシップ関数 $\mu_{R}(x, y)$ は、A、B のメンバシップ関数 $\mu_{A}\left(x_{s}\right) \mu_{B}\left(y_{j}\right)$ を用い て二項関係によって決定される。たとえば

$$
\mu_{R}(x, y)=\mu_{A}(x) \wedge \mu_{B}(y)
$$

のように示すことができる。したがってファジィ集 合 $\mathrm{B}$ は以下の計算で得ることができる。

$$
A \circ R=\int \sup \left[\mu_{A}(x) \wedge \mu_{R}(x, y)\right] / y
$$

ここで、。: $\max$-min 演算、sup : 上限である。

この演算は論理的な関係「If $\mathrm{x}$ is $\mathrm{A}$ then $\mathrm{y}$ is $\mathrm{B} 」(も$ しxが $\mathrm{A} な ら は ゙ y を \mathrm{~B}$ とす。）を表現するもので ある。「 $\mathrm{x}$ is A 」とは異なる入力「 $\mathrm{x}$ is $\mathrm{A} 」$ によって 得られる推論結果 $\Gamma \mathrm{y}$ is $\mathrm{B}$ ’」は次のようにして求める ことができる。

$$
B^{\prime}=\int \sup \left[\mu_{A^{\prime}}(x) \wedge \mu_{R}(x, y)\right] / y
$$

これは、フ产ジィ関倸を表現するためのメンバシ ップ $\mu_{R}(x, y)$ を $\mathrm{A} \rightarrow \mathrm{B}$ の関係として決定しておけ ば「x is A’」の状態を示すメンバシップ関数 $\mu_{A}\left(x_{s}\right)$ から推論結果としてyの状態を示すファジィ集合 B’が求められることを示している。

作成されたルールでは、交通事故類型ごとの発生 要因を考慮する。これにより、段階的なファジィ推 論モデルを構築する。ファジィ推論モデルでは、「IF 〜THEN・・・ルールによって、交通事故発生とそ れに起因する多様な要因との因果関係を明確にする ことを可能としている。

ここで、全ルール数は 27 とする。また、推論ルー ルはすべての交差点において共通して適用可能とす るために、一般化した形式で記述するものとする。 さらに、木構造で表現できる程度ではあるが、推論 の連鎖により結論が導かれる構造とする。

言語変数は、「small」、「medium」、「large」、 「very large」である。各言語変数に対応するメンバ シップ関数を図ー11に示す。これは、岐阜市の事故 多発交差点における交通事故件数の大小の程度を意 味する。「small」は交通事故の発生がほとんどない 交差点の発生件数として規定している。同様に「very large」は交通事故件数の最も多い交差点での発生件 数から規定している。この 2 変数の值から均等な間

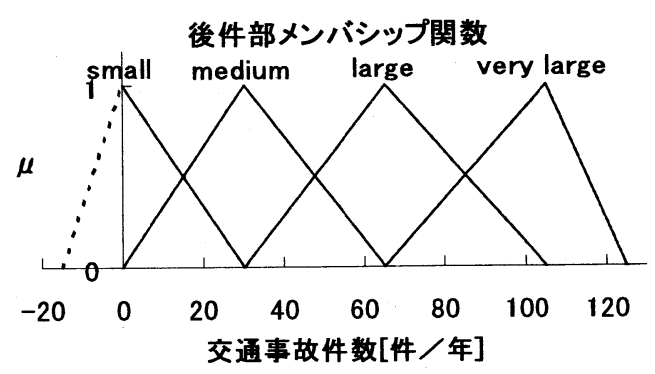

図-11 交通事故件数のメンバシップ関数

隔となるように「medium」「large」を規定している。

\section{（2）ファジィ推論モデルの現況再現性}

ここでは、ファジィ推論モデルの構築のために、 H7〜H9 の交通事故関連データを用いた。ファジィ推 論モデルを規定するパラメータ決定は試行錯誤法に より、これら 3 箇年の実績に対する適合性をもとに モデルを規定した。

これより、経年的な推計が可能となった。ここで はH7〜H9 の交通事故推計結果について述べる。絶対 誤差の総和 347.4、RMSE=5.9 であり、比較的良好な 精度の推計結果が得られた。

ここで、個別交差点の推計結果について分析する。 3 箇年の誤差の合計が最大となったのは、本郷町真 砂町若宮町交差点である。この交差点における交通 事故件数は、過大に推計されている。H7 の場合は、 実測事故件数 29 件に対し、推計值が 46.6 件であり、 17.6 件の過大推計となった。この交差点の構造的な 特徴としては、路面電車が走行することと、道路の 変形度が大きいことが挙げられる。これらに関して、 前者は「運転難易性」の值を、後者は「構造変形度」 の值を大きく設定することとしている。

しかしながら、推計に用いた交差点 24 箇所のうち の 4 箇所は、この交差点と同様に道路の変形があり、 路面電車が走行する。これらの 4 交差点における交 通事故件数の推計値は過大とはならず、良好な值で あった。ここでは、当該交差点における過大推計の 要因を特定できないが、当該交差点では他の交差点 とは異なる要因が影響している可能性がある。

\section{（3）ファジィ推論モデルの適用性}

今回のモデル作成時には使用していないデータ (H10 から H12 まで 3 年間) をモデル検証用として 利用する。ここでは構筑した推計モデルが経年的な 交通状況変化に追従可能かどうかを検証する。

事故件数の推計結果を図-12 に示す。絶対誤差の 総和 $362.2 、 \mathrm{RMSE}=6.7$ であり、当然ながらパラメー 夕推計時の現況再現結果 $(\mathrm{H} 7 \sim \mathrm{H} 9)$ と比較して、推 
計精度の低下がみられる。

ここで、特定の交差点の交通事故件数の経年変化 に着目し、交通事故の推計可能性について議論を行 う。ここでは、前述の市民会館前交差点に着目する。

図一13に市民会館前交差点における事故件数の経年 変化に関する推計結果を示す。これを実績交通事故 件数と経年的に比較すると、その推移に良好に追従 できていることが分かる。

\section{5. 交通安全対策の立案}

作成したファジィ推論モデルは、各交差点の、類 型別の発生要因を考慮する。そのため、特定の類型 事故削減のために実施される安全対策がもたらす効 果を検証することができる。

（1）ファジィ推論モデルへの交通安全対策の導入

交通安全対策実施の影響により、交通事故件数が 変化する様子をモデル上で表現する。

\section{（a）交通安全対策実施と事故要因の関係}

交通事故件数推計ファジィ推論モデルにおいては、 交通安全対策実施により、説明変数の值が変化する。 交通安全対策実施によって变化する説明変数は、「視 認性程度」と、「標示等誘導性」である。

ここで、例として「視認性程度」について述べる。 この交通事故要因は、交通安全対策である「信号機 の大型化」および「明色滑り止舖装」の指標を複 合することで構成される。ここでは、2指標の最高 得点を各 10 ポイント、両者の効果を $5: 3$ として指 標値を算定した。すなわち、当該交差点で実施可能 な箇所すべてに、それぞれの交通安全対策が実施さ れている場合に最大ポイントとなる。これにより、 交通安全対策実施による効果が推計可能となった。

(b) 交通安全対策効果の時間的派減

交通安全対策は交通事故件数削減を目的として実 施されるが、このような安全対策の効果には、時間 的な莪减がある。つまり、「信号機の大型化」や、

「明色滑り止め舗装」などの安全対策は、実施直後 には大いに事故削減の効果を発揮するが、時間の経 過とともに、物理的な老朽化、また、人間の心理面 に作用する「慣れ」のために、効果が派减する。本 モデルでは、これを反映する。具体的には、「視認 性程度」、「標示等誘導性」の值が経年的に $10 \%$ ず つポイントが減少していくものとした。これにより、 安全対策効果の時間的な莪减を推計モデル上で表現 することが可能となった。

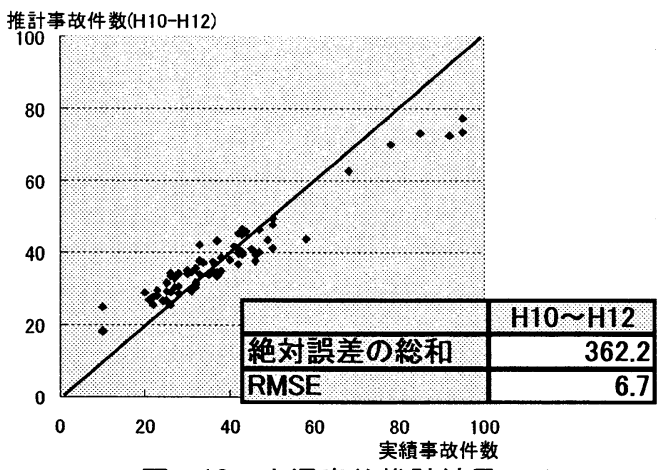

図-12 交通事故推計結果

\section{交通事故件数}

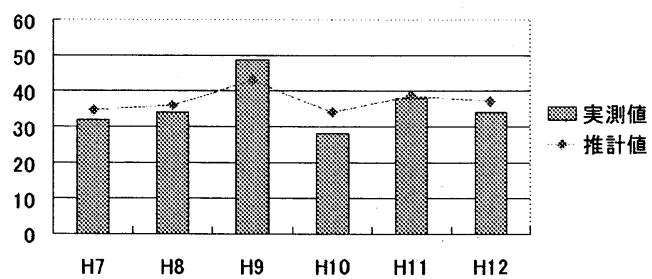

図-13 経年的交通事故変化に関する推定 （市民会館前交差点）

\section{（2）道路交差点における安全対策代替案の策定}

構筑したモデルを用いて、交通安全対策をある特 定の交差点に導入する。ここでは、知識整理におい ても用いた市民会館前交差点について分析する。

選定した交差点における H12 の交通状況と交差点 に交通安全対策を実施するものとする。具体的には、 「信号機の大型化」を交差点全体に、「導流標示の 修正」を交差点内に実施するものとする。これを交 通事故分析画面上で示したものが図ー14である。

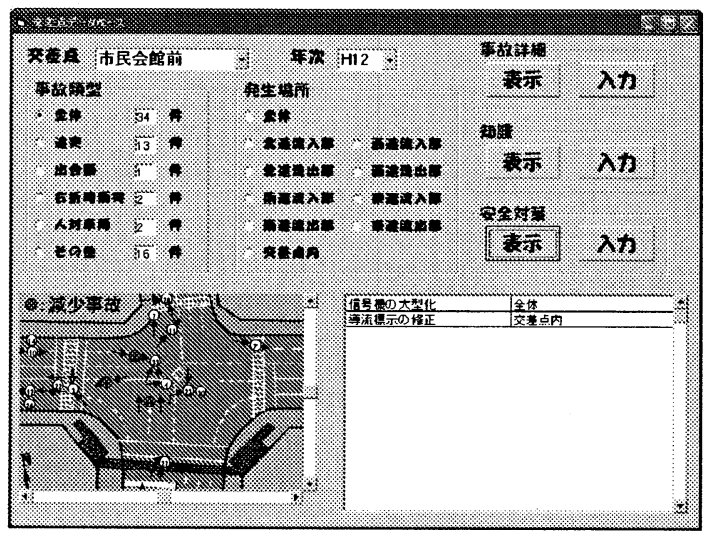

図-14 交通安全対策実施による交通事故件数変化 （市民会館前交差点の場合） 
信号機の大型化はドライバーの注意喚起力を高め、 交差点であることをより認識させる。この結果、追 突事故が発生する危険性を低下させる。

また、導流標示の修正は、車両の進行方向を明確 に示寸ため、車線変更時などにおける側面衝突事故 の危険性を低減させる。

以上の影響から、交差点内においては、設定した 交通安全対策のもとで、次のような交通事故推計が なされる。追突事故が 2 件減少・接触事故が 1 件減 少となる。

\section{（3）安全対策実施による事故件数の経年的推移}

前述のように、本研究における事故件数推計モデ ルは、交通安全対策効果の時間的な減衰を考慮する。 このような設定のもとで、市民会館前交差点に、安 全対策を実施した場合の事故件数推計值の経年的推 移を検証する。ここでは、前節において設定した「信 号機の大型化」と「導流標示の修正」を、H7 から H12 までの各年次でともに実施するものとする。この結 果を図一15に示す。これより、交通安全対策の実施 により、実施年次の事故件数は一旦減少するが、そ の後漸増していく結果が伺える。

\section{6. おわりに}

本研究では、交通事故多発地点での交通安全対策 の立案のため、蓄積された交通事故関連データベー スについて、交通事故要因を抽出し、交通事故要因 に関わる知見として蓄積可能な交通事故要因分析シ ステムを構筑した。これにより、交通事故多発交差 点について、交通事故類型別・交通事故発生位置 (方 向）ごとの交通事故要因を考慮した、交通安全対策 の立案を可能とした。

本研究の成果としては、以下の諸点が挙げられる。 (1)交通事故多発地点における交通事故に関する要因 を分析可能なデータベースシステムを設計し、基 本システムを構築した。このとき、交通安全対策 の立案を効率的に実行可能とするため機能を統合 した。これにより、蓄積された交通事故データベ 一スを有効に利用した交通事故の要因分析が可能 となった。

(2)効果的な交通安全対策導出のための知識獲得の手 順を明示した。この手順に従い、交通事故要因の 分析を行い、これに関する知識の蓄積を行った。

これにより、交通事故要因分析システムを利用し た交通事故多発交差点での分析手順を提示した。

(3)交通事故要因の分析から推論形式で知識を整理し、

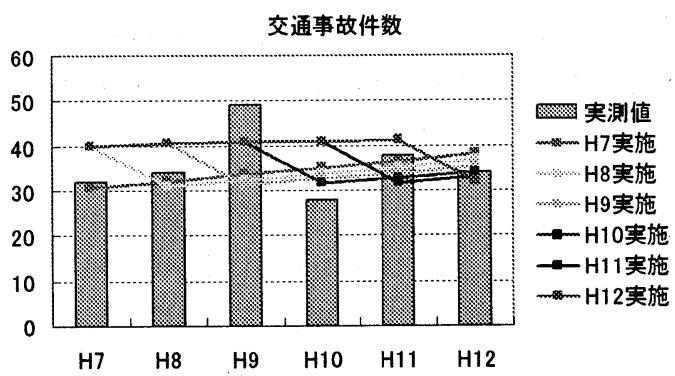

\section{図-15 交通安全対策実施による交通事故 件数の経年的変化（市民会館前交差点）}

交通事故件数推計モデルを作成し、分析システム に統合することにより交通事故多発交差点におい て交通事故件数推計を行った。これにより、交通 安全対策実施による交通事故件数削減効果を推計 可能とした。

また、今後の課題としては以下の点が挙げられる。 (1) 専門家の知識（外生的知識）と、システム内で学 習によって得られる知識 (内生的知識) の整合の 図り方を検討する必要がある。

(2)GIS における各種の地理情報について、データ心゙ 一スの有機的な連動による、有効な活用方法を検 討する必要がある。

\section{【謝辞】}

本研究で使用した交通事故データの収集に関しては、 岐阜県警察本部交通企画課統計分析係のご協力をいた だいた。また本研究における交通安全に関する知識 獲得においては、岐阜県交通事故防止対策委員会に おける議論を参考としている。特に体系的な整理に おいては、岐阜県警察交通部交通企画課・信田正美 調查官に多大なご協力をいただいた。ここに記して感 謝の意を表する次第である。

\section{【参考文献】}

1）岐阜県警察本部交通部：交通事故多発場所等の分析 と防止対策図.

2) Akiyama, T. and Suzuki, T.: Transport Safety Management and Cost-Effectiveness Optimization Problem, Urban Transportation, Journal of the Eastern Asia Society for Transportation Studies, Vol.1, No.3, pp.951-962, 1995.

3）小谷ゆかり, 鈴木崇児, 秋山孝正, 武藤慎一: 交差 点での類型別事故推計モデルに基づく交通安全対策 の評価手法, 土木計画学研究·論文集, Vol. 18, No. 5, pp.971-978, 2001.

4）小谷ゆかり, 鈴木崇児, 秋山孝正 : 類型別事故予測 
モデルを内包した交通安全対策策定方法, 第 19 回交 通工学研究発表会論文報告集, pp.225-228, 1999.

5）秋山孝正, 小川圭一, 寺嶋真穂 : 交通安全対策の組 み合わせ最適化に対する免疫アルゴリズムの適用性 の検討, 土木計画学研究・論文集, Vol. 20, No.4, pp.975-982, 2003.

6）村瀬満記，秋山孝正，奥嶋政嗣 : 交通事故推計のた めのファジィ推論モデルの作成, 第 19 回ファジィシ ステムシンポジウム講演集, pp. 429-432, 2003.

7）村瀬満記，秋山孝正，奥嶋政嗣 : 交通事故分析デー タベースシステムの作成, 土木学会中部支部平成 15 年度研究発表会講演概要集, pp.377-378, 2004.
8）土木学会 : ITS 社会にむけた交通安全研究の方向性 について 2, 2003

9）坂和正敏：ファジィ理論の基礎と応用, 森北出版, 1989

10）本多中二, 大里有生 : ファジィ工学入門, 海文堂出 版, 1989

11）古田均, 小尻利治, 宮本文穂, 秋山孝正, 大野研, 背野康英: ファジィ理論の土木工学への応用, 森北出 版, 1992

\section{交通事故多発交差点に関する事故要因分析システムの構築*}

村瀬 満記**秋山 孝正 ${ }^{* * *}$. 奥嶋 政嗣****

交通事故多発交差点における交通安全対策策定のためには、交通事故多発交差点の的確な交通事 故要因の把握が必要不可欠である。交通事故多発交差点は、規模、形状、交通状況など多様な要素 が複雑に関連しており、交通事故要因の把握のためには、これらの項目相互の関連性および交通事 故発生との因果関係を、交通事故要因に関わる知見として蓄積する必要がある。本研究では，交通 事故多発地点での交通事故関連データベースを作成するとともに、交通事故要因分析システムを構 築することにより、交通事故要因に関して分析する。また、交通安全対策効果を計測可能な交通事 故推計モデルを構築し、分析システムを利用した交通安全対策の立案方法を示す。

Construction of Analysis System for Traffic Accidents Estimation in Intersections* By Mitsunori Murase ${ }^{* *}$, Takamasa AKIYAMA ${ }^{* * *}$ Masashi OKUSHIMA ${ }^{* * * *}$

The traffic safety planning has received much attention in terms of reduction of danger in driving. The causality of the plural factors have to be clarified in the estimation of traffic accidents at the intersection. The model with fuzzy reasoning was introduced to the estimation of the number of traffic accident in the intersection. In this study, The causality of the plural factors analysis is designed and basic model is constructed for traffic accidents estimation in Intersections. The type of accidents may be separated to consider the accurate estimation in the study. 